\title{
A Comparison of Anatomical Measurements of the Infraorbital Foramen of Skulls of the Modern and Late Byzantine Periods and the Golden Ratio
}

\author{
Comparación de las Medidas Anatómicas del Foramen Infraorbitario en Cráneos \\ de la Época Bizantina Tardía, Edad Moderna y la Proporción Áurea
}

Bakirci, S.*; Kafa, I. M.**; Coskun, I.**; Buyukuysal, M. C.*** \& Barut, C.****

BAKIRCI, S.; KAFA, I. M.; COSKUN, I.; BUYUKUYSAL, M. C. \& BARUT, C. A Comparison of anatomical measurements of the infraorbital foramen of skulls of the modern and late Byzantine periods and the Golden Ratio. Int. J. Morphol.,34(2):788-795, 2016.

SUMMARY: The aim of this study was to examine the morphometric characteristics of the infraorbital foramen of skulls of people living in modern society and in the late Byzantine period, to ascertain the symmetry or asymmetry of the two halves of the skulls by measuring the linear distance between various landmarks, to evaluate at the conformity between the infraorbital foramen and the golden ratio by calculating the ratios between these linear distances, and to set out the differences or similarities between the skulls of these different periods. It was found in the study that the morphometric characteristics of the infraorbital foramen in skulls of the modern period were $47.05 \%$ circular, $41.17 \%$ oval and $11.76 \%$ atypical (semilunar and triangular) on the right, and $70.58 \%$ circular and 29.41 $\%$ oval on the left, while those of the Byzantine period were $46.06 \%$ circular and $53.3 \%$ oval on the right, and $50 \%$ circular and $50 \%$ oval on the left. It was found that the measurements across the infraorbital foramen of the Byzantine skulls averaged $2.93 \pm 1.05 \mathrm{~mm}$ and $3.15 \pm 1.03 \mathrm{~mm}$ on the right side and $2.62 \pm 0.97 \mathrm{~mm}$ and $3.16 \pm 0.68 \mathrm{~mm}$ on the left vertically and horizontally respectively, and those of the modern period measured $2.32 \pm 0.50 \mathrm{~mm}$ and $3.00 \pm 0.92 \mathrm{~mm}$ on the right and $2.48 \pm 0.45 \mathrm{~mm}$ and $2.76 \pm 0.65 \mathrm{~mm}$ on the left vertically and horizontally respectively. The ratio between the distances from the outer orbital wall of the IOF to the sagittal plane and the piriform aperture were $1.46 \pm 0.25 \mathrm{~mm}$ and $1.40 \pm 0.21 \mathrm{~mm}$ for left and right respectively for the Byzantine skulls, and $1.24 \pm 0.24 \mathrm{~mm}$ and $1.29 \pm 0.42$ $\mathrm{mm}$ for the modern skulls. A significant difference was found between the ratio obtained and the golden ratio for each of the periods (modern and Byzantine) ( $\mathrm{p}<0.005)$. A comparison of anatomical characteristics of the infraorbital foramen of people living at different historical periods is important for anthropologists and knowing morphological types and amassing knowledge on the proportional calculation of location is important for dentistry, maxillofacial surgery and algology.

KEY WORDS: Infraorbital foramen; Golden ratio; Byzantine period; Asymmetry; Maxilla.

\section{INTRODUCTION}

The blood vessels and nerves which pass through the infraorbital foramen (IOF) situated on the front surface of the maxilla lateral to the piriform aperture are responsible for supplying and innervating the lower eyelid, the alae of the nose, the upper lip, the cheek, and the incisor and premolar teeth (Williams et al., 1989). The infraorbital nerve is the continuation of the maxillary branch of the trigeminal nerve after it enters the infraorbital canal on the base of the orbit. The distribution of this nerve as it exits from the IOF is extremely important for orbital, oral, maxillofacial and reconstructive surgery. Relief of problems caused in this area by trigeminal neuralgia can be provided by anaesthesia. In addition, localization of the IOF is an essential reference point for dentists, anaesthetists and acupuncturists in terms of a neural block. Knowing the anatomical characteristics of the IOF and asymmetrical/symmetrical condition and also knowing gender and population differences provide significant benefits in the success of local anaesthetics and in reducing the risks of surgery.

The golden ratio expresses harmony between the parts of a whole and is an irrational number. It is approximately 1.618. This aesthetic ratio frequently appears in many structures of the human anatomy, as between the structure

\footnotetext{
* Department of Anatomy, School of Medicine, Düzce University, Duzce, Turkey.

** Department of Anatomy, School of Medicine, Uludag ` University, Bursa, Turkey.

*** Department of Biostatistics, School of Medicine, Bülent Ecevit University, Zonguldak, Turkey.

***** Department of Anatomy, School of Medicine, Bahcesehir University, Istanbul, Turkey.
} 
of the lips, eyes and nose in the human face; between the width and height of teeth (this ratio is frequently used by dentists in dental prosthesis), in the fingers, between the length of the first two phalanges and the length of the finger; and in the ear, between the anatomical structures forming the extremities (Prasanth, 2012).

The golden ratio is noticeable not only in the human body but can also be used in areas of life such as architecture and the design of utensils in daily use, as well as in cosmetic surgery and anatomy. The fact that the golden ratio appears in so many anatomical structures raises the question as to whether there is a relationship between the location of the infraorbital foramen, which is of such importance on the face, and the golden ratio. In a previous study by Ikiz (1999) on skulls of the Byzantine period only, an investigation was made of the position of the infraorbital foramen relative to the supraorbital foramen, and also of its distances from the infraorbital margin and from the midsagittal line. This study was taken as the base of the present study, and its purpose was to compare the data provided by IOF morphometric types and linear measurements of skulls from populations living in the Anatolian geography in the present day and in the late Byzantine period, and to investigate whether there was a relationship close to the golden ratio between IOF localization and other bone landmarks.

\section{MATERIAL AND METHOD}

Thirty-six human skulls were obtained from Uludag University Medical Faculty Anatomy Department for this study. Twenty of these were from present-day society, while sixteen dated from the late Byzantine period. These latter had been obtained in 1984 from the Nicea archaeological site at Iznik in the Bursa province. In the case of skulls which were found during the course of the study to be damaged, such as those with breakages on the lower margin of the orbit or the lateral margin of the piriform aperture, evaluation of the morphometric measurements of these structures was not performed. Digital photographs were obtained of the skulls marked in millimetres by means of a Canon 450d camera. The photographs were converted to a format suitable to the scale, calibration was performed and they were prepared for measurement by the program Scion Image Software ver. 4.0.3.2 (Barut \& Ertilav, 2011). IOF typing was performed on each half of the skulls (Singh, 2011; Aggarwal et al., 2015), and measurements were made of 12 parameters from the digital photographs of each half of each skull (Fig. 1, Table I). These parameters were the distances from the IOF to, in order, the infraorbital margin, the lateral margin of the piriform aperture, the sagittal plane passing through the centre line of the skull, the transverse plane passing through the lower side of the piriform aperture, the sagittal plane passing through lateral side of the orbit, the upper side of the orbit, and the sides of the alveoli for the upper teeth. Also, measurements were made of the vertical and horizontal widths of the IOF, and the distance between the left and right IOF and the width of the piriform aperture on this plane. Apart from these parameters, another parameter which was examined was the angle between the lines joining the IOF to the spina nasalis anterior, the nasal bones on the midline and the intersection point of the frontal bone (Fig. 1, Table I). The ratios 1) between the distances of the IOF to the sagittal plane and the piriform aperture passing through the outer wall of the orbit $(\mathrm{A} / \mathrm{B}) ; 2)$ the IOF to the sagittal plane passing through the outer orbital wall and the sagittal plane passing through

Table I. Parameters.

\begin{tabular}{ll}
\hline & Distances are measured to infraorbital for amen \\
\hline A & Distances from the IOF to the sagittal plane passing through lateral side of the orbit \\
B & Distances from the IOF to the lateral margin of the piriform aperture \\
C & Distances from the IOF to the sagittal plane passing through the centre line of the skull \\
C1 & Width of the piriform aperture \\
C2 & Distance between the left and right IOF \\
D & Distances from the IOF to the lower side of the orbit \\
E & Distances from the IOF to the transverse plane passing through the lower side of the piriform aperture \\
F & Distances from the IOF to the sides of the alveoli for the upper teeth \\
G & Distances from the IOF to the upper side of the orbit \\
H & Distances from the IOF to junction of the frontal bone with the nasal bones \\
I & Vertical widths of the IOF \\
J & Horizontal widths of the IOF \\
K & Distances from the IOF to the zygomaticofacial foramen \\
Angle & The angle between the lines joining the IOF to the spina nasalis interior, the nasal bones on the midline and the meeting \\
& point of the frontal bone
\end{tabular}




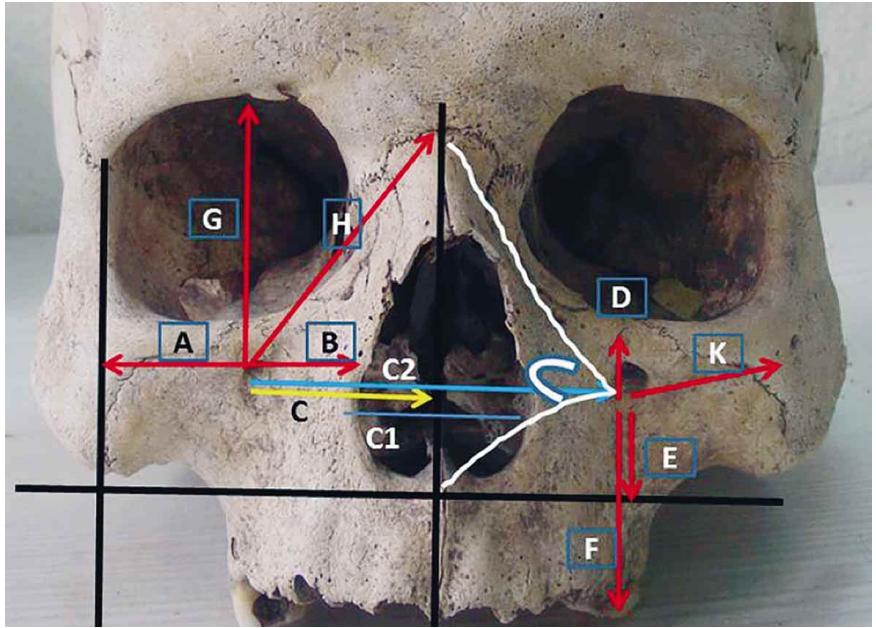

Fig. 1. Parameters.

the midline of the skull (A/C); 3) between the distance between the transverse width of the piriform aperture and the left and right side IOFs (C2/C1); and 4) between the distance from the IOF to the infraorbital margin and the distance of the transverse plane passing through the upper margin of the piriform aperture (D/E) were examined for the golden ratio. The values of the parameters measured were compared between left and right sides and between the modern and Byzantine populations.

Statistical Method. Statistical analysis in the study was performed using the program SPSS 19.0. Descriptive statistics for the continuous variable in the study were shown with minimum, maximum, mean and standard deviation. Conformity to normal distribution was examined by Shapiro Wilk test. Conformity of measurements to the golden ratio was examined by the Wilcoxon single sample test and the Bland Altman methods. For independent two-group comparisons, the Mann Whitney $\mathrm{U}$ test and the Independent sample $\mathrm{t}$ tests were used. The presence or lack of difference between the left and right side measurements were examined with the paired samples $t$ test. In all statistical comparisons, a p value of below 0.05 was accepted as statistically significant.

\section{RESULTS}

IOF width mean measurements were calculated as follows: for the Byzantine period skulls, right side vertical and horizontal measurements were $2.93 \pm 1.05 \mathrm{~mm}$ and $3.15 \pm 1.03 \mathrm{~mm}$ respectively, and on the left these were $2.62 \pm 0.97 \mathrm{~mm}$ and $3.16 \pm 0.68 \mathrm{~mm}$; for the modern skulls the equivalent measurements were $2.32 \pm 0.50 \mathrm{~mm}$ and $3.00 \pm 0.92 \mathrm{~mm}$ on the right and $2.48 \pm 0.45 \mathrm{~mm}$ and $2.76 \pm 0.65 \mathrm{~mm}$ on the left. Classification of the shape of the infraorbital foramen was performed for each period (Table II).

Table III shows the median, minimum maximum, mean and standard deviation values of the descriptive statistics of IOF and related measurements carried out on the skulls of the late Byzantine and modern periods.

A statistically significant difference was found between $\mathrm{H}-\mathrm{R}$ values obtained from the late Byzantine and modern samples. This parameter was greater in the late Byzantine bone samples and the difference was significant $(\mathrm{p}=0.016)$. No significant difference was found between the two groups in terms of other measurement values.

When the values obtained from the late Byzantine and modern samples were compared, no statistically significant difference was found between the groups other than H-R parameters (Table III), and so left-right comparisons were performed on the skulls as a single group. The C/A values obtained on the right were higher than those obtained on the left, and the difference was significant $(\mathrm{p}<0.05)$. No statistically significant difference was found between the other measurement values obtained from the right side and those obtained from the left side (Table IV). In this way, the results obtained can be evaluated as supporting symmetry.

Table $\mathrm{V}$ shows the ratios between the distances measured for the skulls of both periods, the $\mathrm{A} / \mathrm{B}, \mathrm{C} / \mathrm{A}$, $\mathrm{C} 1 / \mathrm{C} 2$ and $\mathrm{E} / \mathrm{D}$ ratios, and the statistical comparison of them. No statistically significant difference were found between the two groups when these ratios were evaluated.

The relationship between the golden ratio and the ratios mentioned above (Table V), were evaluated onesample Wilcoxon test and the Bland Altman method (Fig. 2). As no significant difference emerged between them, the Byzantine and modern groups were evaluated as a single group. A significant difference was noted between

Table II. Classification of shape of the infraorbital foramen.

\begin{tabular}{lcccccc}
\hline & \multicolumn{3}{c}{ Right } & \multicolumn{3}{c}{ Left } \\
\cline { 2 - 7 } & Circular (\%) & Oval (\%) & Atipik (\%) & Circular (\%) & Oval (\%) & Atipik (\%) \\
\hline Bizans & 46.6 & 53.3 & --- & 50 & 50 & --- \\
Modern & 47.05 & 41.17 & 11.76 & 70.58 & 29.41 & --- \\
\hline
\end{tabular}



periods and the Golden Ratio. Int. J. Morphol.,34(2):788-795, 2016.

Table III. Statistical analysis of measurement values obtained from skulls from the late Byzantine period and modern society. Mann Whitney U Test.

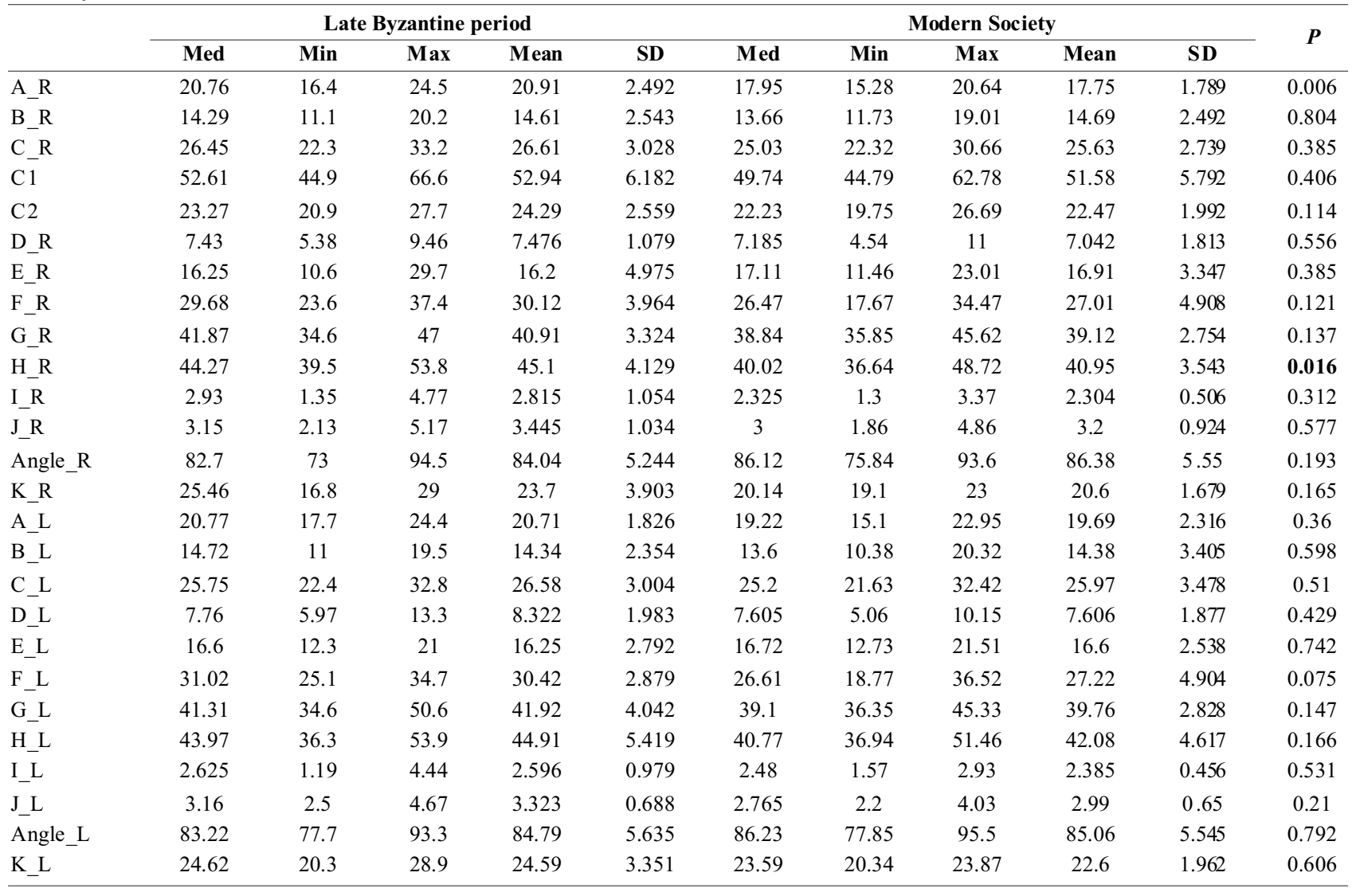

Table IV. Comparison of values obtained from the right and left sides. Paired samples t test.

\begin{tabular}{|c|c|c|c|c|c|c|c|c|c|c|c|}
\hline & & & $\mathbf{R i}$ & & & & & Lef & & & $\boldsymbol{D}$ \\
\hline & Med & Min & Max & Mean & SD & Med & Min & Max & Mean & SD & $F$ \\
\hline $\mathrm{A} / \mathrm{B}$ & 1.3456 & 0.92 & 1.98 & 1.3647 & 0.27135 & 1.3967 & 0.98 & 2.17 & 1.4641 & 0.32605 & 0.117 \\
\hline $\mathrm{C} / \mathrm{A}$ & 1.3387 & 1.07 & 1.83 & 1.3610 & 0.21772 & 1.3461 & 0.96 & 1.80 & 1.3033 & 0.19710 & 0.024 \\
\hline $\mathrm{E} / \mathrm{D}$ & 2.3077 & 1.34 & 4.33 & 2.3572 & 0.78701 & 2.0411 & 1.28 & 3.25 & 2.1615 & 0.61091 & 0.073 \\
\hline A & 19.71 & 15.28 & 24.46 & 19.5339 & 2.69339 & 20.63 & 15.1 & 24.36 & 20.2262 & 2.08694 & 0.187 \\
\hline B & 14.27 & 11.13 & 20.19 & 14.6465 & 2.46376 & 14.425 & 10.38 & 20.32 & 14.3564 & 2.80576 & 0.521 \\
\hline $\mathrm{C}$ & 25.65 & 22.28 & 33.24 & 26.1835 & 2.88445 & 25.61 & 21.63 & 32.79 & 26.3068 & 3.16346 & 0.753 \\
\hline D & 7.28 & 4.54 & 11 & 7.2874 & 1.42416 & 7.75 & 5.06 & 13.3 & 7.9964 & 1.92412 & 0.048 \\
\hline $\mathrm{E}$ & 16.58 & 10.56 & 29.72 & 16.5122 & 4.26785 & 16.6 & 12.34 & 21.51 & 16.4055 & 2.62219 & 0.439 \\
\hline $\mathrm{F}$ & 28.6 & 17.67 & 37.43 & 28.7661 & 4.57306 & 29.915 & 18.77 & 36.52 & 28.9664 & 4.16134 & 0.605 \\
\hline $\mathrm{G}$ & 39.48 & 34.63 & 47.03 & 40.127 & 3.15461 & 40.73 & 34.63 & 50.62 & 40.9364 & 3.63333 & 0.065 \\
\hline $\mathrm{H}$ & 42.74 & 36.64 & 53.79 & 43.297 & 4.34226 & 41.86 & 36.34 & 53.89 & 43.6273 & 5.1573 & 0.395 \\
\hline I & 2.33 & 1.3 & 4.77 & 2.593 & 0.88207 & 2.48 & 1.19 & 4.44 & 2.5 & 0.77668 & 0.769 \\
\hline $\mathrm{J}$ & 3.13 & 1.86 & 5.17 & 3.3387 & 0.97361 & 2.985 & 2.2 & 4.67 & 3.1714 & 0.67623 & 0.595 \\
\hline Angle & 83.4 & 73.02 & 94.49 & 85.0583 & 5.38646 & 84.9 & 77.65 & 95.5 & 84.9127 & 5.4617 & 0.397 \\
\hline $\mathrm{K}$ & 21.93 & 16.76 & 29 & 22.7462 & 3.61762 & 23.59 & 20.32 & 28.91 & 23.9256 & 2.99483 & 0.551 \\
\hline
\end{tabular}

the ratios obtained and the golden ratio $(\mathrm{p}<0.05)$. This showed that the ratios which we obtained cannot be identified with the golden ratio, however close they may be in value. The $\mathrm{A} / \mathrm{B}$ ratios obtained from the right and left sides were numerically close to the golden ratio, but this was not statistically significant. Thus, there was no relationship between the ratios which we obtained and the golden ratio (Table VI). 
BAKIRCI, S.; KAFA, I. M.; COSKUN, I.; BUYUKUYSAL, M. C. \& BARUT, C. A Comparison of anatomical measurements of the infraorbital foramen of skulls of the modern and late Byzantine periods and the Golden Ratio. Int. J. Morphol.,34(2):788-795, 2016.

Table V A comparison of the ratios between the measured distances.

\begin{tabular}{|c|c|c|c|c|c|c|c|c|c|c|c|}
\hline & \multicolumn{5}{|c|}{ Late Byzantine period } & \multicolumn{5}{|c|}{ Modern Society } & \multirow[t]{2}{*}{$P$} \\
\hline & Med & Min & Max & Mean & SD & Med & Min & Max & Mean & SD & \\
\hline A/B Right & 1.4598 & 1.07 & 1.98 & 1.4608 & 0.25724 & 1.2427 & 0.92 & 1.59 & 1.2398 & 0.24715 & 0.077 \\
\hline A/B Left & 1.4084 & 1.23 & 1.88 & 1.4789 & 0.21896 & 1.2928 & 0.98 & 2.17 & 1.4479 & 0.42709 & 0.654 \\
\hline C/A Right & 1.3041 & 1.07 & 1.54 & 1.2835 & 0.16091 & 1.3741 & 1.10 & 1.83 & 1.4617 & 0.24786 & 0.088 \\
\hline C/A Left & 1.2640 & 1.08 & 1.45 & 1.2693 & 0.12228 & 1.3594 & 0.96 & 1.80 & 1.3406 & 0.25838 & 0.426 \\
\hline $\mathrm{C} 1 / \mathrm{C} 2$ & 2.2624 & 1.90 & 2.44 & 2.1962 & 0.20535 & 2.2690 & 2.03 & 2.97 & 2.3054 & 0.2802 & 0.481 \\
\hline E/D Right & 2.1222 & 1. 34 & 4.33 & 2.2208 & 0.80173 & 2.5658 & 1.48 & 4.05 & 2.5344 & 0.77154 & 0.186 \\
\hline E/D Left & 1.9396 & 1.28 & 2.90 & 2.0378 & 0.55317 & 2.2892 & 1.49 & 3.25 & 2.3099 & 0.67228 & 0.346 \\
\hline
\end{tabular}
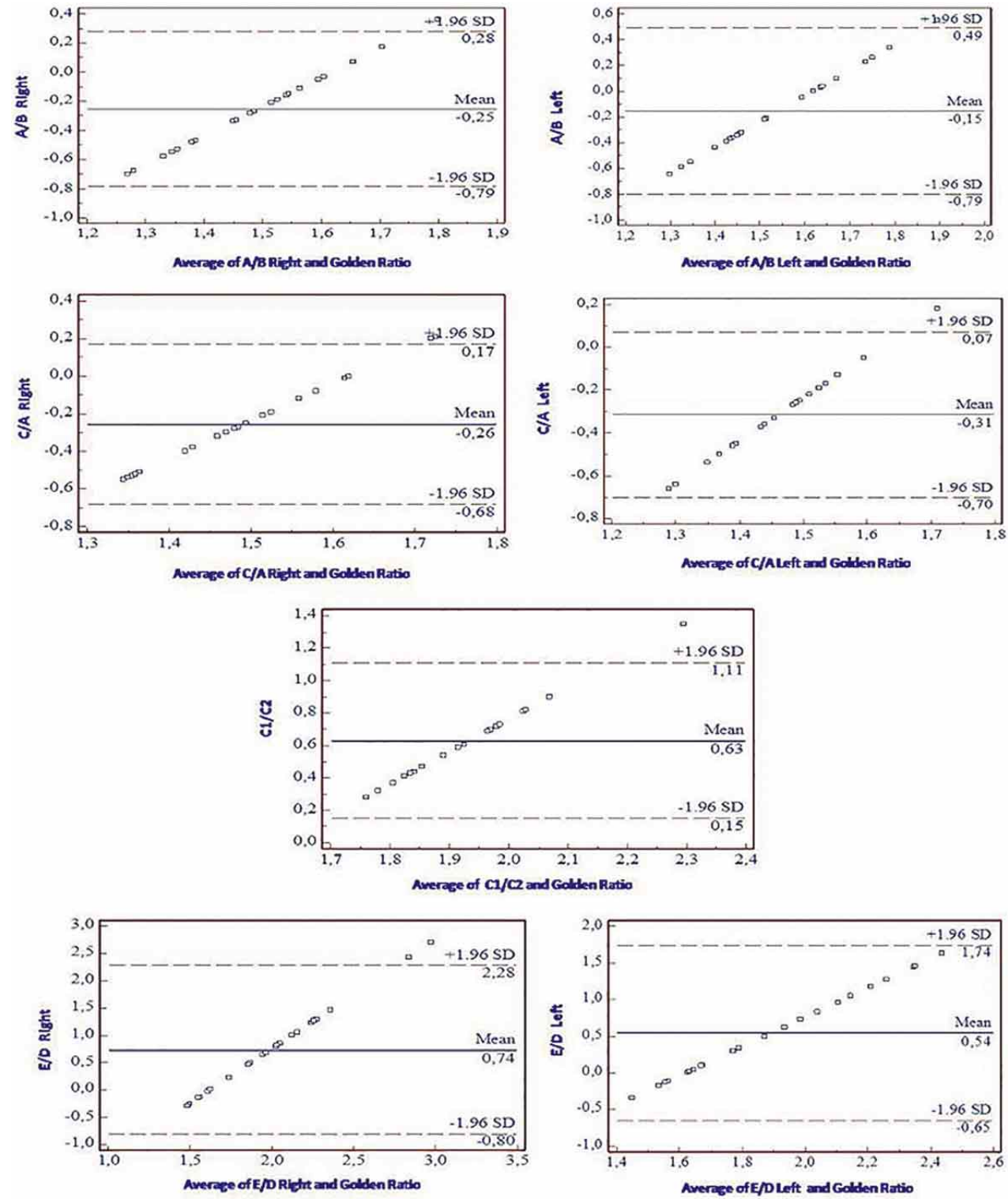

Fig. 2. Distribution graphs of ratio values against golden ratio (Bland and Altman). 

periods and the Golden Ratio. Int. J. Morphol.,34(2):788-795, 2016.

Table VI. Relationship of ratios obtained relating to the infraorbital foramen and the golden ratio.

\begin{tabular}{|c|c|c|c|c|c|c|c|}
\hline & \multicolumn{5}{|c|}{ All working group } & \multirow[b]{2}{*}{ Golden Ratio } & \multirow[b]{2}{*}{$P$} \\
\hline & Med & Min & Max & Mean & SD & & \\
\hline A/B Right & 1.3456 & 0.92 & 1.98 & 1.3647 & 0.27135 & 1.618 & 0.001 \\
\hline A/B Left & 1.3967 & 0.98 & 2.17 & 1.4641 & 0.32605 & 1.618 & $<0.05$ \\
\hline C/A Right & 1.3387 & 1.07 & 1.83 & 1.3610 & 0.21772 & 1.618 & $<0.001$ \\
\hline C/A Left & 1.3461 & 0.96 & 1.80 & 1.3033 & 0.19710 & 1.618 & $<0.001$ \\
\hline $\mathrm{C} 1 / \mathrm{C} 2$ & 2.2690 & 1.90 & 2.97 & 2.2508 & 0.24557 & 1.618 & $<0.001$ \\
\hline E/D Right & 2.3077 & 1.34 & 4.33 & 2.3572 & 0.78701 & 1.618 & 0.001 \\
\hline E/D Left & 2.0411 & 1.28 & 3.25 & 2.1615 & 0.61091 & 1.618 & 0.003 \\
\hline
\end{tabular}

\section{DISCUSSION}

Knowledge of the differences between anatomical structures of different age groups, genders, races and populations is of great importance to surgeons, forensic specialists, anaesthesiologists and dentists. Various nations or races have mixed for long historical periods and so have partially lost their distinguishing characteristics. The morphometric comparison of the anatomical structures of people who have lived in the same place but at different historical periods has been the topic of studies. In the present study, skulls of people living in the late Byzantine period and the modern period were compared in terms of the shape and dimensional characteristics of the IOF, and its distance to the upper, lower and lateral sides of the orbit and the lateral and lower sides of the piriform aperture, and to the dental alveoli on the lower side of the maxilla. In the Byzantine skulls, two IOF types (circular and oval) were found both on the right and left sides, and neither type predominated numerically over the other (Table II). In the modern skulls, the numbers of oval and circular IOF were similar on the right side with a few more of the circular type. On the left side, an appreciably greater number of circular IOF were found than of the oval type. In addition, on the right side in the modern skulls, a small number of atypical IOF (triangular or semilunar) were observed. In a study of bones of the Byzantine period, I'kiz classified the position of the IOF in relation to the supraorbital foramen, and reported that it was most frequently located outside a vertical line passing through the outer edge of the supraorbital foramen (right $61.3 \%$, left $64.5 \%$ ). In a study by Singh in which a classification was made similar to that in our study, it was reported that the frequency of oval IOF on the right side in the Indian population was $65.4 \%$ and circular $34.5 \%$; on the left, the proportion of oval IOF was $75.54 \%$, and circular $30.09 \%$ (Barut \& Ertilav). In our study, circular IOF were seen more frequently in the skulls of both the Byzantine and the modern skulls ( $48.3 \%$ on the right side, and $58.8 \%$ on the left) (Table VI). In addition, the presence of a hooklike bony process was observed on the upper side of the IOF of some of the skulls (three Byzantine and four modern) (Fig. 3). The presence of a hook-shaped bony process must be considered for local anaesthesia, as is could make access to the IOF more difficult.

The left and right average of the distance from the IOF to the lower edge of the orbit was $7.65 \mathrm{~mm}$ for the Byzantine period and $7.89 \mathrm{~mm}$ for the modern samples. The values for the two periods were very close to one another, and no statistical difference was found between them. When a comparison was made with the literature, it was seen that the Byzantine period values were closer to the values published by Kaskayasi $(7.19 \mathrm{~mm})(7-10)$ (Table VII). The distance from the IOF to the piriform aperture was 17.75 $\mathrm{mm}$ for the Byzantine period and $18.75 \mathrm{~mm}$ for the modern period. No statistical difference was shown between the two periods. It was found that the results for the two periods are closer to the results published in the literature by Macedo (17.67 mm) (Macedo et al., 2009).

The ratio between the distances from the IOF to the sagittal plane passing through the outer wall of the orbit and the piriform aperture $(\mathrm{A} / \mathrm{B})$ was calculated as $1.46 \pm 0.25 \mathrm{~mm}$

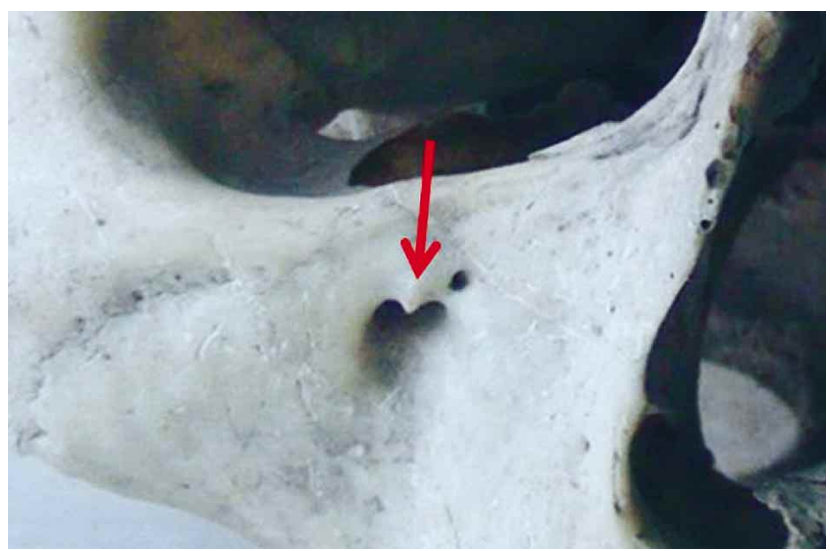

Fig. 3. Hook-shaped tubercle. 
and 1.40 $\pm 0.21 \mathrm{~mm}$ for skulls of the Byzantine period and $1.24 \pm 0.24 \mathrm{~mm}$ and $1.29 \pm 0.42 \mathrm{~mm}$ for the modern skulls, for the right and left sides respectively. The ratio between the distance from the IOF to the infraorbital margin and the distance to the transverse plane crossing the lower margin of the piriform aperture (D/E) was calculated as $0.47 \pm 0.75$ $\mathrm{mm}$ and $0.51 \pm 0.75 \mathrm{~mm}$ for the Byzantine period skulls and $0.39 \pm 0.13 \mathrm{~mm}$ and $0.43 \pm 0.13 \mathrm{~mm}$ for the modern skulls, for the right and left sides respectively. The variation between minimum and maximum distances between the IOF and various landmarks is very great, and this increases the difficulty of the work of clinicians, but the better average distances are known, the more this will help to reduce risk of complications. We are of the opinion that the information which we have provided on these ratios in this study will make it easier for anaesthetists, dentists, acupuncturists and surgeons to determine the location of the IOF on an individual basis.

It is of note that the parameters measured in this study were very similar for the two groups, and that apart from one parameter (H-R) there was no statistically significant difference between the groups. Interpreting this, it can be said that the structure of the IOF is similar in the skulls of the late Byzantine period and those of the modern period, and that no differences have occurred in the infraorbital foramen with the passing of time. It can be claimed that after approximately 600 years no appreciable change has taken place in the structure of the infraorbital foramen in this area.

In the normal growth of the human body, a small amount of asymmetry will occur. Asymmetry occurring in the face does not frequently cause any aesthetic problem. However important facial symmetry may be for attractiveness according to some writers, others say that asymmetry occurring in the face can add to its beauty (Ferrario et al., 1994, 2001; Baudouin \& Tiberghien, 2004; Zaidel \& Cohen, 2005; Ercan et al., 2008). Ercan et al., conducted a shape analysis of the two-dimensional digital photographs of the faces of 321 healthy young people, and identified a large number of asymmetries in the linear

Table VII. Comparison of infraorbital foramen-piriform aperture (IOF-PA) and infraorbital foramen-infraorbital margin (IOF-IOM) distances.

\begin{tabular}{lcc}
\hline Study & IOF-PA & IOF-IOM \\
\hline Singh (2011) & 15.56 & 6.16 \\
Macedo et al. (2009) & 17.67 & 6.37 \\
Hindy \& Abdel Rouf (1993) & 17.23 & 6.10 \\
Kaskayasi et al. (2001) & 14.70 & 7.19 \\
Aggarwal et al. (2015) & 15.19 & 6.33 \\
This study, Byzantine period & 17.75 & 7.65 \\
This study, Modern period & 18.75 & 7.89 \\
\hline
\end{tabular}

measurements of the two sides of the faces. They found that both in males and in females, the left side of the face was often dominant. They found that the distances from the most lateral point on the zygomatic arch and the most lateral point of the zygomaticofrontal suture to the nasion and subnasale, which were used as midline landmarks in the study, were asymmetrical between left and right. In that study, the right and left halves of the human face were found to be asymmetrical in many respects, so that in our study we expected the same to be true of the distances on the left and right sides of the skulls. We found however, just the opposite to be true, and that the skulls tended to be symmetrical (Zaidel \& Cohen). Based on our results, it can be said that the location and structure of the IOF and the bone reference points which we used for measurement are symmetrical (Table IV). Therefore, maxillofacial surgeons can expect the important bony structure of the face to be symmetrical even if the soft tissue structure is asymmetrical.

\section{CONCLUSION}

The infraorbital foramen shows great variation in location, form, and whether it has a hook-shaped bony projection. The distance from the IOF to the lower margin of the orbit and the lateral margin of the piriform aperture have a wide differential value, and show great variation from one individual to another. For this reason, knowing the average values of the distances can provide great benefit in practical applications on an individual basis. Therefore, we believe that knowledge of the ratios between the distances from the IOF to various anatomical landmarks for each individual will be useful in determining the location of the IOF in facial surgery, dental treatment and acupuncture.

BAKIRCI, S.; KAFA, I. M.; COSKUN, I.; BUYUKUYSAL, M. C. \& BARUT, C. Comparación de las medidas anatómicas del foramen infraorbitario en cráneos de la época Bizantina tardía, la edad moderna y la proporción áurea. Int. J. Morphol., 34(2):788795,2016

RESUMEN: El objetivo fue examinar las características morfométricas de los forámenes infraorbitarios en cráneos de personas que viven en la sociedad moderna y aquellas que vivieron en el periodo bizantino tardío, para determinar la simetría o asimetría de las dos mitades de los cráneos. Se realizó la medición de la distancia lineal entre varios puntos de referencia, para evaluar la conformidad entre el foramen infraorbitario (FO) y la proporción áurea, mediante el cálculo de la relación entre esas distancias lineales, así como las diferencias y similitudes entre los cráneos de estos períodos. En relación a las características morfométricas, se encontraron en cráneos de la época moderna FO circulares 
(47,05\%), ovalados $(41,17 \%)$ y atípicos (semilunar y triangular) en un $11,76 \%$, del lado derecha, y en el lado izquierdo estos porcentajes correspondieron a circulares $(70,58 \%)$ y ovalados $(29,41 \%)$. Por su parte, los cráneos del período bizantino presentaron FO circulares $(46,06 \%)$ y ovalados $(53,3 \%)$ del lado derecho, mientras que del lado izquierdo fueron circulares $(50 \%)$ y ovalados $(50 \%)$. Se encontró que las medidas del FO de los cráneos bizantino tuvo un promedio de 2,93 $\pm 1,05 \mathrm{~mm}$ y $3,15 \pm 1,03 \mathrm{~mm}$ en el lado derecho, y 2,62 $\pm 0,97 \mathrm{~mm}$ y $3,16 \pm 0,68 \mathrm{~mm}$ a la izquierda, vertical y horizontal, respectivamente; y en el período moderno midieron $2,32 \pm 0,50 \mathrm{~mm}$ y $3,00 \pm 0,92 \mathrm{~mm}$ a la derecha y $2,48 \pm 0,45$ $\mathrm{mm}$ y $2,76 \pm 0,65 \mathrm{~mm}$ a la izquierda, en medidas verticales y horizontales respectivamente. La relación entre las distancias de la pared orbitaria exterior del FO al plano sagital y la apertura piriforme fue de $1,46 \pm 0,25 \mathrm{~mm}$ y $1,40 \pm 0,21 \mathrm{~mm}$, a izquierda y derecha respectivamente, para los cráneos bizantinos; y 1,24 $\pm 0,24 \mathrm{~mm}$ y

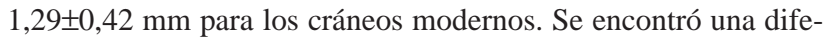
rencia significativa entre la proporción obtenida y la proporción áurea para cada uno de los períodos (moderno y bizantino) (p $<0,005)$. La comparación de las características anatómicas del FO de individuos que vivieron en diferentes períodos históricos es valioso para los antropólogos y los conocimientos sobre el cálculo proporcional de la ubicación del FO son importantes en la odontología, cirugía maxilofacial y el estudio del dolor.

PALABRAS CLAVE: Foramen infraorbitario; Proporción áurea; Época Bizantina; Asimetría; Maxila.

\section{REFERENCES}

Aggarwal, A.; Kaur, H.; Gupta, T.; Tubbs, R. S.; Sahni, D.; Batra, Y. K. \& Sondekoppam, R. V. Anatomical study of the infraorbital foramen: A basis for successful infraorbital nerve block. Clin. Anat., 28(6):753-60, 2015.

Barut, C. \& Ertilav, H. Guidelines for standard photography in gross and clinical anatomy. Anat. Sci. Educ., 4(6):348-56, 2011.

Baudouin, J. Y. \& Tiberghien, G. Symmetry, averageness, and feature size in the facial attractiveness of women. Acta Psychol. (Amst.), 117(3):313-32, 2004.

Ercan, I.; Ozdemir, S. T.; Etoz, A.; Sigirli, D.; Tubbs, R. S.; Loukas, M. \& Guney, I. Facial asymmetry in young healthy subjects evaluated by statistical shape analysis. J. Anat., 213(6):663-9, 2008 .

Ferrario, V. F.; Sforza, C.; Poggio, C. E. \& Tartaglia, G. Distance from symmetry: a three-dimensional evaluation of facial asymmetry. J. Oral Maxillofac. Surg., 52(11):1126-32, 1994.

Ferrario, V. F.; Sforza, C.; Ciusa, V.; Dellavia, C. \& Tartaglia, G. M. The effect of sex and age on facial asymmetry in healthy subjects: a cross-sectional study from adolescence to midadulthood. J. Oral Maxillofac. Surg., 59(4):382-8, 2001.
Hindy, A. M. \& Abdel-Raouf, F. A study of infraorbital foramen, canal and nerve in adult Egyptians. Egypt. Dent. J., 39(4):57380, 1993.

Ikiz, I. Variations of the supraorbital notch or foramen and relationship of the infraorbital foramen. Uludag Univ. Tip. Fak. Derg., 26:9-12, 1999.

Kazkayasi, M.; Ergin, A.; Ersoy, M.; Bengi, O.; Tekdemir, I. \& Elhan, A. Certain anatomical relations and the precise morphometry of the infraorbital foramen--canal and groove: an anatomical and cephalometric study. Laryngoscope, 111(4Pt. 1):609-14, 2001.

Macedo, V. C.; Cabrini, R. R. \& Faig-Leite, H. Infraorbital foramen location in dry human skulls. Braz. J. Morphol. Sci., 26(1):35-8, 2009.

Prasanth, G. N. S. Golden Ratio in Human Anatomy. PhD Thesis. Chittur, Government College Chittur, 2012.

Singh, R. Morphometric analysis of infraorbital foramen in Indian dry skulls. Anat. Cell Biol., 44(1):79-83, 2011.

Williams, P. L.; Warwick, R.; Dyson, M. \& Bannister, L. H. Gray's Anatomy. 37 $7^{\text {th }}$ ed. Edinburgh, Churchill Livingstone, 1989. pp.337-67.

Zaidel, D. W. \& Cohen, J. A. The face, beauty, and symmetry: perceiving asymmetry in beautiful faces. Int. J. Neurosci., 115(8):1165-73, 2005.

Correspondence to:

Dr. Sinan Bakırcı, MD, Assistant Professor

Duzce University Medical Faculty

Department of Anatomy

Konuralp 81620

Duzce

TURKEY

Email: sinanbakirci@duzce.edu.tr

Received: 03-12-2015

Accepted: 28-01-2016 